\title{
Récits d'Ellis Island: um olhar subjetivo a partir da memória do outro
}

\author{
Tatiana Barbosa Cavalari*
}

\begin{abstract}
Resumo: O presente artigo pretende discutir a importância dos documentos de arquivo para a composição da obra literária/documentário Récits d'Ellis Island (Georges Perec e Robert Bober, 1980). A partir de fotos, fichas médicas e informações históricas, ambos os artistas realizarão um trabalho de memória coletiva que se liga também às memórias individuais, levando-se em conta que membros de suas famílias poderiam também ter desembarcado nessa ilha, em busca de uma nova vida, no início do século XX.

Palavras-chave: documentário; fotografia; memória coletiva; autobiografia.
\end{abstract}

Resumen: En este artículo se analiza la importancia de los documentos de archivo para la composición de la obra literaria/documental Récits d'Ellis Island (1980), de Georges Perec y Robert Bober. A partir de fotos, registros médicos e informaciones históricas, ambos artistas realizaron un trabajo de memoria colectiva vinculado igualmente a las memorias individuales, teniendo en cuenta que los miembros de sus familias también podrían haber desembarcado en esa isla, en busca de una nueva vida, a principios del siglo $\mathrm{XX}$.

Palabras clave: documental; fotografía; memoria colectiva; autobiografía.

Abstract: This article discusses the importance of archive footage for the composition of the literary artwork/documentary Récits d'Ellis Island (1980), by Georges Perec and Robert Bober. From photos, medical records and historical information, both artists held a collective memory that also links to individual memories, taking into account that members of their families could have landed on the same island in search of a new life, in the early twentieth century.

Keywords: documentary; photography; collective memory; autobiography.

Résumé: L'article se propose de réfléchir sur l'importance des documents d'archive dans la composition de l'oeuvre littéraire/documentaire Récits d'Ellis Island (Georges Perec et Robert Bober, 1980). A partir de photographies, fiches médicales et d'informations historiques, les deux artistes vont réaliser un travail de mémoire collective qui s'attache aussi aux mémoires individuelles, en tenant compte que les membres de leurs familles auraient pu avoir débarqué dans cette île, à la recherche d'une nouvelle vie, au début du $\mathrm{XX}^{\mathrm{e}}$ siècle.

Mots-clés: documentaire; photographie; mémoire collective; autobiographie.

* Doutoranda. Universidade de São Paulo, Faculdade de Filosofia, Letras e Ciências Humanas, Programa de Pós-Graduação em Letras. 05037001, São Paulo, Brasil. E-mail: tatsbar@hotmail.com

Submissão do artigo: 30 de dezembro de 2015. Notificação de aceitação: 09 de fevereiro de 2016. 
O trabalho de parceria entre o escritor Georges Perec e o cineasta Robert Bober, que resultou em livro e documentário homônimos (Récits d'Elllis Island, 1980) começa quando decidem ir a Nova Iorque conhecer Ellis Island, entrar em contato com o lugar, observar, preparar-se para o trabalho que ainda viria pela frente. É interessante observar, logo no início da seção "Repérages" ${ }^{1}$ como Perec descreve sua primeira ida a Nova Iorque e o que conheciam previamente sobre o lugar: "Fizemos uma primeira viagem à Nova Iorque na primeira quinzena de junho de 1978. Não conhecíamos de Ellis Island nada mais que algumas fotografias antigas".

Esse trecho é fundamental, já que faz refletir sobre o primeiro contato que tiveram com o lugar. Foi através de "algumas fotos antigas" que iniciaram seu projeto: através delas iniciou-se o desejo de levar o trabalho adiante, de investigar o local até então "abstrato" (só visto através de fotos), de vê-lo pessoalmente e de compará-lo com as fotos antigas: "Tratava-se para nós, incialmente, de manter contato com esse lugar ainda abstrato, e em seguida preparar a filmagem que deveríamos realizar no outono". Antes de se tornar uma "autobiografia provável" e válida para ambos, a investigação do lugar e das fotos revela um importante trabalho documental: tanto o livro quanto o filme são, além de autobiográficos, também biográficos e documentais, históricos.

Trata-se de uma obra literária peculiar, já que concebida para tornar-se o roteiro de um filme (realizado em parceria com o cineasta Robert Bober), que nos conta uma história coletiva: Ellis Island foi, durante o período de 1892 a 1924, o ponto de chegada de milhares de emigrantes europeus que vieram tentar a sorte na América do Norte. Nessa época, quase dezesseis milhões de pessoas passaram pela ilha, a maioria não ficando mais que algumas horas, $\mathrm{e}$ apenas dois a três por cento delas recusadas a entrar no país, segundo os dados constantes no livro.

Curioso refletir sobre como o projeto começou: a partir da leitura de um artigo anunciando a reabertura de Ellis Island para visitação pública, Bober lembra-se de uma história contada pela sua mãe que trata da ida de seu bisavô polonês aos Estados Unidos, munido de algumas economias, para tentar uma vida melhor. Na viagem, ficou doente e, por isso, obrigado a voltar à terra natal.

A partir desta história, o cineasta decide convidar Georges Perec para uma parceria: filmagem e escrita sobre esse lugar onde nenhum dos dois nunca esteve, mas que faz parte de uma história comum: ambos são de origem polonesa e poderiam ter tido destinos diferentes do que tiveram, caso seus parentes tivessem conseguido entrar (no caso de Bober, já que seu bisavô foi recusado

1. As duas citações dessa página são do livro Récits d'Ellis Island, seção Repérages, p. 94. 
ao tentar entrar na ilha) ou decidido partir (no caso de Perec, que teve os pais mortos na França, na Segunda Guerra Mundial, e foi adotado pela tia materna). Apesar de não conhecerem o lugar antes mesmo de lá estarem, iniciam certa familiaridade com a ilha e com as pessoas que por lá passaram através da observação das fotos de Lewis W. Hine tiradas no começo do século ${ }^{2}$, ou seja, no momento em que os emigrantes chegavam diariamente aos Estados Unidos em busca de um destino melhor. Mesmo à distância, houve um processo de aproximação entre o escritor, o cineasta, o lugar e, por consequência, esses milhares de desconhecidos, que viveram muito antes deles, aos quais Perec e Bober, mesmo que indiretamente, se sentem intrinsecamente ligados.

O livro é constituído por três partes: a primeira é L'île des larmes, na qual Perec faz uma apresentação do lugar e de sua história a partir de documentos e informações levantadas; a segunda é Description d'un chemin e tem um texto mais pessoal evocando suas relações pessoais (dele e de Bober), suas origens e seus reais questionamentos sobre exílio, identidade, memórias. A última parte, intitulada Mémoires, traz depoimentos de pessoas que passaram por Ellis Island.

Escrever uma história (individual ou coletiva) utilizando-se da presença (ou não) de imagens para recompor a memória serão as tentativas de escrita presentes em ambas as narrativas, tanto a fílmica quanto a literária. A partir dessa afirmação, pretendo verificar de que forma estas relações entre texto, memória e imagem serão "manipuladas" por Perec e Bober.

Como essas relações se refletirão na tentativa de evocação das memórias individuais e coletivas? Como utilizar-se de imagens públicas para também contar a própria história?

Filmar e fotografar esse lugar - além de trazer à tona possíveis destinos aos quais os autores não tiveram acesso - possibilita fazer emergir, principalmente, uma parte da história coletiva: a proveniência dos emigrantes, sua travessia, sua chegada à Ellis Island, o tratamento reservado a essas pessoas: tudo estará documentado, tanto no livro quanto no filme. Assim, a manipulação de fotos de arquivo - consultadas pelos artistas para a composição das cenas do documentário - será fundamental, tanto para a criação cinematográfica quanto para a criação literária de Perec. As fotos serão como "motores" da escrita e da realização do documentário.

Além disso, a manipulação de arquivos que contém dados históricos sobre o lugar farão parte do processo de criação dos artistas: as descrições, as listas

2. Na entrevista realizada com Robert Bober e publicada sob o título Le regard et l'absence, o cineasta afirma que um ano antes da filmagem, ele e Perec estiveram em Nova Iorque para se documentar, para procurar pessoas e endereços. Foi nessa época que tiveram o contato maior com a obra de Lewis Hine nos arquivos da New York Public Library. (Cahiers Georges Perec 9, p. 245-254). 
indicando o número de pessoas que chegaram, o volume de objetos abandonados, a quantidade de perguntas feitas aos recém-chegados, serão o material consultado e reelaborado por Perec: esses documentos nos remetem às intermináveis listas preparadas por este nos seus variados momentos de composição: tanto em manuscritos quanto em projetos inacabados e, no caso de Récits d'Ellis Island, funcionando como elemento de composição do texto literário.

Não há uma recusa ou negação à apresentação destes dados históricos, ao contrário: trechos da narração do guia contando histórias reais do local para os turistas são mostrados no documentário. Mas, o que fica claro tanto para quem lê o livro quanto para quem assiste ao filme é que os números e as estatísticas serão apenas instrumentos para que os realizadores possam criar suas reflexões, interferindo de maneira subjetiva, poética, peculiar, fugindo do "lugar-comum" daquilo que está sendo mostrado pelo guia. Além de turístico, o lugar é histórico e, acima de tudo, é o lugar onde se pode falar de exílio, de memória, de homenagem. Se lembrarmos, mais uma vez, que ambos os realizadores são poloneses de origem judia e, de alguma forma, seus parentes poderiam ter chegado aos Estados Unidos no início do século por meio de Ellis Island, percebemos que há uma intenção autobiográfica na composição da obra, mesmo que tratem de uma história que não lhes pertence, mas que se liga a eles de alguma maneira, como se nesta ilha "estivesse inscrito em algum lugar em uma história que poderia ser a minha", "como se fizesse parte de uma autobiografia provável, de uma memória potencial" 3 (Perec, 1990: 99).

Assim, escrever uma autobiografia provável, a partir de uma memória potencial, significa trazer à tona uma história que não lhes pertence diretamente, mas que leva à reflexão, que os induz a questionar o que foi o lugar. "O que teria sido de mim e de minha família se tivessem passado por aqui?", é uma das possíveis questões que pode tê-los levado a iniciar o projeto literário/cinematográfico.

\section{As fotos de arquivo como fontes para a criação do documentário/livro}

A cena inicial do filme será fundamental para destacar essa importante relação entre as fotos, o texto e o documentário; logo nas primeiras cenas, nos deparamos com uma imagem interessante: Perec folheia um álbum de fotos enquanto o filme é rodado; há um álbum presente e há também um livro onde cenas desse filme reaparecem, como se um estivesse "dentro" do outro, num quase efeito de mise en abîme (é o filme que está dentro do álbum? Ou é o álbum que está dentro do filme?).

3. No original: "était inscrit quelque part dans une histoire qui aurait pu être la mienne", "comme s'il faisait partie d'une autobiographie probable, d'une mémoire potentielle" 
Esse mélange entre filme e livro é uma maneira de representar a verdadeira fusão entre o trabalho dos dois artistas. Independentemente da ordem em que foram concebidos, os dois suportes aparecem com o mesmo propósito: uma obra dupla, composta por duas vozes: a do escritor (que comenta as imagens dadas) e a do cineasta (que dá imagens para os comentários do escritor), num constante movimento de trabalho conjunto, simultâneo, interativo: o ato de folhear o álbum remete ao projeto autobiográfico ao mesmo tempo que o projeto pertence aos outros, um material literário e visual que não será como um álbum de família, e sim como um álbum "coletivo, partilhado".

As fotos de anônimos (aquelas coletadas em arquivos, tratadas como documentos históricos) funcionam, assim, como "memória comum a todos os emigrantes, eternizando não indivíduos particulares, mas gestos, rituais e emoções" (Lawniczak, 2006: 234).

Esse compartilhamento de imagens anônimas, tanto no livro quanto no filme, representa o desejo de busca de ambos os artistas: a busca por uma voz, por uma imagem, mas que não seja uma voz ou uma imagem individual: que ela seja uma voz coletiva, uma imagem coletiva, uma memória coletiva, já que as pessoas ali representadas são anônimas; as únicas referências a elas são dados gerais e objetivos nos retratos feitos, em grande parte, pelo célebre fotógrafo Lewis Hine.

Na terceira parte do livro (ausente no filme), intitulada Album, percebemos que as fotos funcionam como uma representação do percurso desses emigrantes. Seus títulos designam as etapas sucessivas da passagem obrigatória pela ilha (como Le débarquement ou Arrivé à Ellis Island): as fotos de Lewis Hine reproduzidas no livro apresentam indicações generalizantes como "jeune juive russe à Ellis Island" ou "grand-mère juive à Ellis Island", por exemplo. Ou seja, não passam de dados oficiais, vistos e apresentados somente em sua superfície. $^{4}$

4. As fotos apresentadas são todas extraídas do livro Récits d'Ellis Island, 1995, P.O.L., e as páginas correspondentes constam da legenda de cada uma delas. 


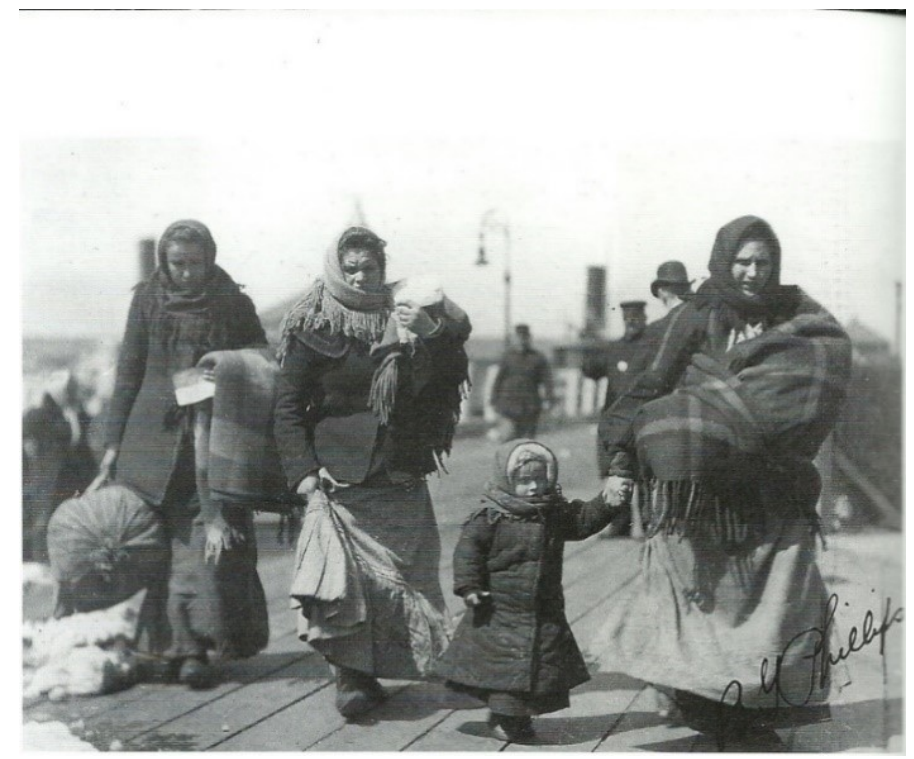

Figura 1. Foto intitulada "Le débarquement", tirada em 1907 por Burt G. Phillips (p.72)

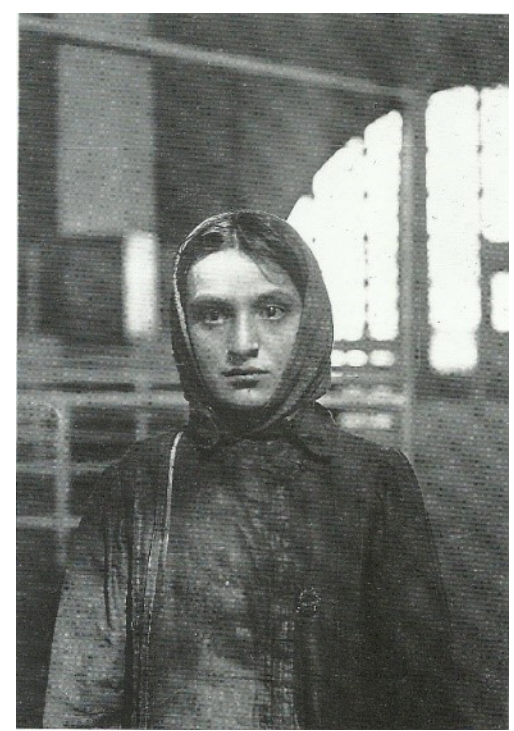

Figura 2. "Jeune Juive russe à Ellis Island", de 1905, por Lewis Hine (p. 77) 


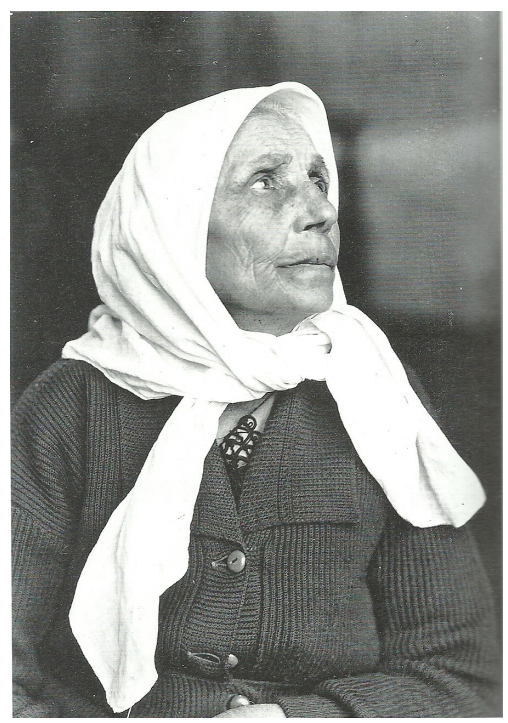

Figura 3. "Grand-mère juive à Ellis Island, de 1926, por Lewis Hine (p. 78)

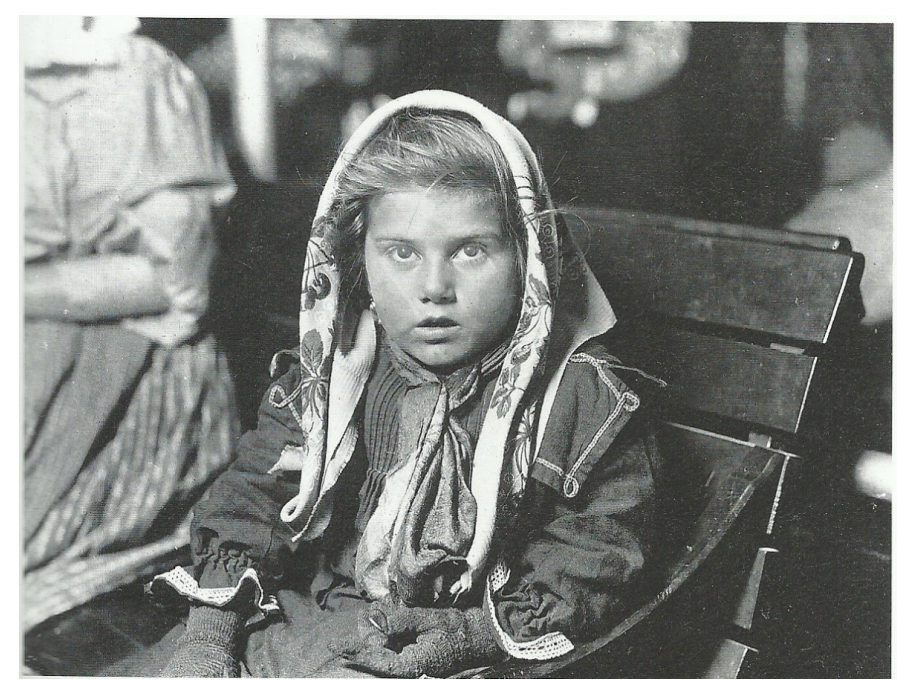

Figura 4. "Une petite italienne reçoit son premier penny", de 1926, por Lewis Hine (p. 79)

Já nas imagens das salas abandonadas não vemos no texto quaisquer comentários, explicações ou dados informativos, mas sim questionamentos sobre o que poderiam ter sido, como poderiam ter funcionado tais lugares: "a câmera 
varre silenciosamente as salas ou mostra uma sucessão de planos fixos com, como comentário, a voz "off" que exprime a impossibilidade de explicações (ou talvez a renúncia voluntária a elas?)" (Lawniczak, 2006, p. 234).

O texto literário, portanto, explicita essa incapacidade de explicações: apesar de serem capazes de ver, não é possível encontrar explicações para tais imagens, não há como fazer com que elas digam ou expliquem algo: "Isso não quer dizer nada, querer fazer falar essas imagens, forçá-las a dizer o que não saberiam dizer" (Perec, 1990: 41), já que há um intervalo temporal importante entre os fatos ocorridos e a época da realização do documentário. Nesse momento há apenas vestígios de um passado, presos sob a artificialidade de um preto de branco das fotos antigas que portam uma possível "evidência enganosa", conforme o trecho a seguir (que nos oferece uma demonstração dos espaços vazios deixados no texto):

sous la tranquilité factice de ces photographies figées une fois pour toutes dans l'évidence trompeuse de leur noir et blanc,

comment reconnaître ce lieu?

restituer ce qu'il fut?

comment lire ces traces?

comment aller au-delà,

aller derrière

ne pas nous arrêter à ce qui nous est donné à voir

ne pas voir seulement ce que l'on savait d'avance que l'on verrait?

Comment saisir ce qui n'est pas montré, ce qui n'a pas

été photographié, archivé, restauré, mis en scène?

Comment retrouver ce qui était plat, banal, quotidien,

Ce qui était ordinaire, ce qui se passait tous les jours?

(Perec, 1990: 37)

Confrontando os documentos históricos do passado (relatórios, fichas médicas e principalmente fotografias) e associando essas histórias coletivas às imagens do presente (filmagens e fotografias atuais do local), Perec e Bober experimentam sensações distintas: se dão conta da presença inegável dessas pessoas no passado, ao mesmo tempo em que percebem a impossibilidade de reconstituir esse tempo, o que acentua ainda mais a questão da presença/ausência nas imagens. "é isso que nos é dado a ver e é somente isso que podemos mostrar" (Perec, 1990: 45).

Na tentativa de restituir o tempo, o escritor e o cineasta vão sofrer a mesma "decepção" na tentativa de rememoração da memória que vimos a partir da $C \hat{a}$ mara Clara de Barthes: vão se dar conta que o fluxo temporal da fotografia é contraditório, nos dá uma ilusão de volta ao tempo impossível de ser reestabelecida: não há possibilidade de ligá-lo ao mundo real, ou seja, vemos a foto, só 
nos damos conta que isso ocorreu no passado e não há mais nada a ser mudado, não há tempo a ser recuperado, restituído.

Essa impossibilidade de restituição de um passado que não pertenceu a nenhum dos artistas é que os moverá na direção da procura, mesmo que nunca cheguem, de fato, a reconstituir qualquer coisa. $\mathrm{O}$ instante da foto nunca mais será resgatado, mas estará registrado para sempre. No cinema, pelo contrário, a pose nunca se fixará, será sempre "levada e negada pela sequência contínua das imagens", segundo Barthes (1981: 118).

Apesar disso, essas imagens imóveis, essas "poses negadas" nos revelam uma interessante fusão entre literatura e cinema, que será potencializada no momento em que o livro apresenta planos cinematográficos do documentário, ou quando Perec aparece no filme folheando um álbum, como já vimos. Esses dois exemplos reforçam a ideia de inexatidão do fluxo do tempo, da ausência de sequência das imagens, da relação de mise en abîme entre texto, imagem fixa e imagem em movimento.

\section{W e Ellis Island: porções de memória cercadas de esquecimento por todos os lados}

A relação entre Récits d'Ellis Island e W ou a memória da infância, outra obra de caráter autobiográfico de Georges Perec, parte do princípio de que ambas se iniciaram a partir da manipulação de fotos antigas. No caso de $W$, as fotos são familiares e fazem parte do processo de criação de textos sobre a memória da infância do autor, ou seja, são declaradamente autobiográficas, mesmo que, à medida em que lemos o texto, nos damos conta de que as memórias são, em grande parte, fictícias e têm sua escrita "incentivada" pela manipulação dessas fotos. Esse texto é composto de duas partes: a autobiográfica, criada a partir da observação das fotos, e outra chamada de ficcional pelo autor. Além disso, há um outro ponto em comum entre as duas obras: ambas terão a ilha como ponto de chegada, mesmo que de maneiras diferentes. A partir da leitura do texto final de $W$, quando finalmente uma ilha fictícia - apresentada no início do texto - se torna real, quando há uma descrição do que realmente se passava ali, temos a impressão de que o que está sendo apresentado não se refere unicamente à imaginação do escritor, mas pode ter relações com leituras anteriores (ou inclusive observação de fotos, por que não?) sobre os campos de concentração, ou como foram descobertos após o fim da guerra. Temos simplesmente a impressão, pois não podemos afirmar que é a descrição de algo real, mas as alusões aos campos são claras:

Quem penetrar um dia na Fortaleza a princípio encontrará apenas uma série de peças vazias, longas e cinzentas. O ruído de seus passos ressoando sob as altas 
abóbadas de concreto lhe causará medo, mas ele deverá prosseguir por muito tempo seu caminho antes de descobrir, enterrados nas profundezas do chão, os vestígios subterrâneos de um mundo que acreditará ter esquecido: um grande número de dentes de ouro, de alianças, de óculos, milhares e milhares de peças de roupa amontoadas, fichários empoeirados, provisões de sabão de má qualidade... (Perec, 1995: 194).

Trata-se, porém, de um texto ficcional, e o trecho citado acima fecha o livro, deixando a cargo do leitor fazer suas possíveis relações entre ficção e fatos vividos, relatados ou imagens vistas.

Quando falamos de Récits d'Ellis Island é impossível não nos lembrar desse trecho descritivo final de $W$, isso porque esta é uma das marcas do trabalho de escrita de Perec: descrever exaustivamente (objetos ou lugares) quando há algo a ser dito, mas que não se realiza a partir de palavras.

No caso de Ellis Island, sabemos que as histórias ali passadas são reais, ou seja, que o livro faz referência a fatos que estão documentados no filme, tratando de pessoas que realmente lá estiveram: o texto literário tem, portanto, um caráter mais poético que documental.

A descrição exaustiva (antes de nos dar a impressão da leitura de um relatório ou de aparentar certa estranheza pela enumeração de objetos), ajuda a refletir sobre a questão da passagem do tempo, da memória e das questões autobiográficas (e biográficas) presentes em toda a obra.

A relação que estabelecemos entre o trecho de $W$ e as descrições do livro Ellis Island diz respeito ao fato de ambas trazerem à tona a ideia de objetos acumulados, em estado de abandono, deterioração, assim como a memória daqueles que passaram por ali, sempre comparando as fotos de arquivo com as imagens atuais.

A questão é: em $W$, tudo não passa de uma alusão, uma alegoria aos campos. Em Ellis Island, todavia, mais do que documentar uma história real, a questão vai além: trata-se de homenagear os que por ali passaram a partir de vestígios frágeis que provocam certas hesitações e reflexões no momento da leitura do texto.

As reflexões são mais intensas quando nos deparamos com as constatações levantadas pelo escritor. Apesar de observarem os objetos, de fotografá-los, de filmá-los, todo esse trabalho de reconstituição não parece possível, nem provável de realizar. Uma das descrições das salas, citada acima, poderia ser assim explicitada: "É somente isso que podemos mostrar, todo o resto deve ser imaginado. Não é possível reconstituir um tempo passado, não há como resgatar a memória de quem esteve por aqui. Há apenas traços".

Por mais que não haja (claramente) uma menção aos campos de concentração nesses textos sobre Ellis Island - até porque todas as pessoas que ali 


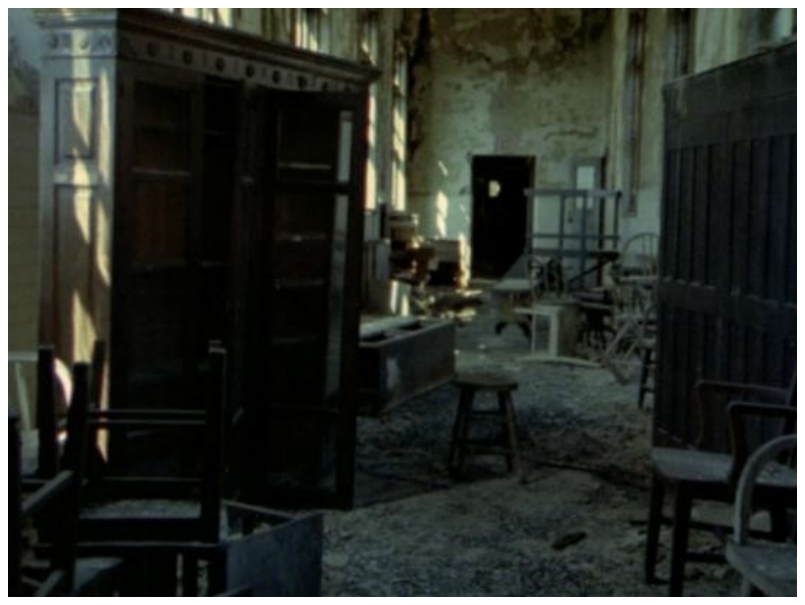

Figura 5. Salas abandonadas na Ellis Island atual.

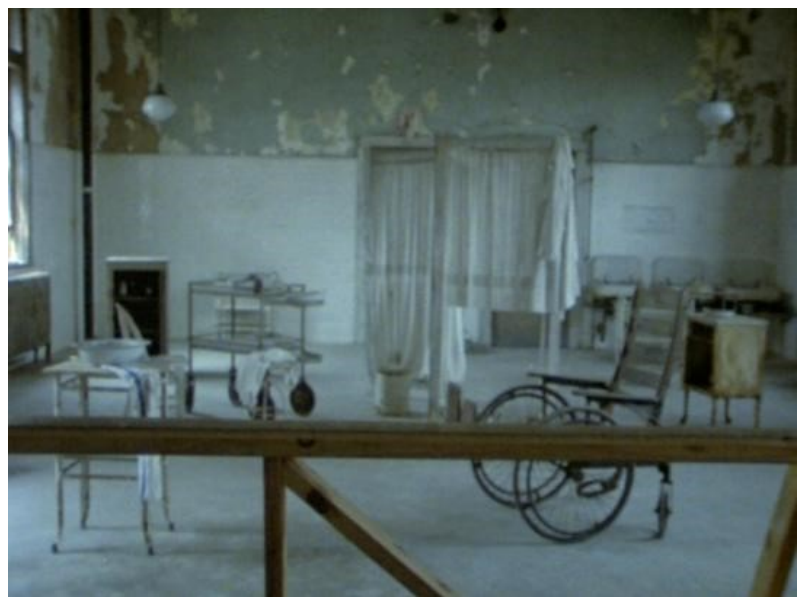

Figura 6. Imagens de uma enfermaria abandonada em Ellis Island.

estiveram, em teoria, o fizeram por vontade própria - as indagações trazidas pelo texto literário e que se relacionam às questões autobiográficas dos realizadores nos remetem inevitavelmente ao trecho de $W$ que explicita essa alusão aos campos e, então, nos fazem ler Ellis Island a partir deste ponto de vista: assim como testemunhos ausentes nos campos, Perec e Bober serão também, em Ellis Island, testemunhos de um lugar ao qual não pertencem e tudo o que podem fazer para tentar se aproximar desse lugar é descrevê-lo e (re) fazêlo em imagens para que o leitor/espectador possa, enfim, fazer suas relações, 
assim como o fez o leitor de W: "eis-me aqui, eu que fui apenas uma testemunha ausente dos campos, nos lugares, mas tudo que eu posso ver, e fazer ver, são traços, relíquias dos campos, da destruição em massa" (Perec, 1975: 44). Mesmo que essa relação com os campos não seja direta, ela permeia ambas as obras, $W$ e Ellis Island, como nos explicam Chauvin e Madini (1997: 67): ${ }^{5}$ "Ellis Island, como W, é uma figuração oblíqua do aniquilamento [...]Ellis Island é ao mesmo tempo o oposto da deportação e um espaço de representação possível para ela".

Portanto, a alusão aos campos será tão sutil quanto a utilização das fotos. Não sabemos quem são as pessoas nas fotos, assim como nunca saberemos como são, de fato, os campos. Escrever o texto e filmar o documentário tornam-se, então, trabalhos de pura criação; além disso, esse trabalho pode ser considerado uma declaração de impotência sobre um tempo que não volta, levando em conta uma poética do desaparecimento e da ausência. Começa em $W$, com a ilha ficcional, um lugar imaginário, e se fixa aqui, em Ellis Island, uma ilha real, um não-lugar, como veremos adiante.

Não podemos afirmar, entretanto, que olhar Ellis Island signifique unicamente fazer alusão aos campos de concentração e à guerra. Diferentemente do texto ficcional de $W$, o livro e o filme trazem fotos de arquivos que nos mostram pessoas vivas, felizes, esperançosas, e não unicamente morte e destruição. As etapas de chegada, a espera, a "triagem" dos emigrantes, estão documentadas em fotos extremamente tocantes, como esta que une a filmagem atual do documentário e uma foto de arquivo:

\section{Olhando para rostos desconhecidos}

A partir do trabalho literário e das imagens a ele incorporadas, temos em Ellis Island uma verdadeira viagem entre passado e presente. Ao nos apresentarem uma história coletiva, os realizadores do projeto buscam, de certa forma, integrar a essa história características autobiográficas, como já vimos.

Mas a poesia do texto literário não se limita a contar a história coletiva através do apagamento dos rostos expostos naquelas fotos antigas. Apesar da impossibilidade de reconstituir fielmente o passado e a história dessas pessoas, a intenção do trabalho artístico acaba sendo também uma tentativa de "humanizar" essa multidão, particularizar histórias (o que será ainda mais evidente quando acontecem as entrevistas com emigrantes da época), direcionar nosso olhar disperso na multidão, fazer com que enxerguemos, no caos e no aban-

5. Texto citado no artigo de Cécile Tourneur, Les dispositifs de fiction cinématographique au sein du documentaire Récits d'Ellis Island, de Georges Perec et Robert Bober (1980), publicado na revista eletrônica Conserveries mémorielles, n. 6, de 2009. 


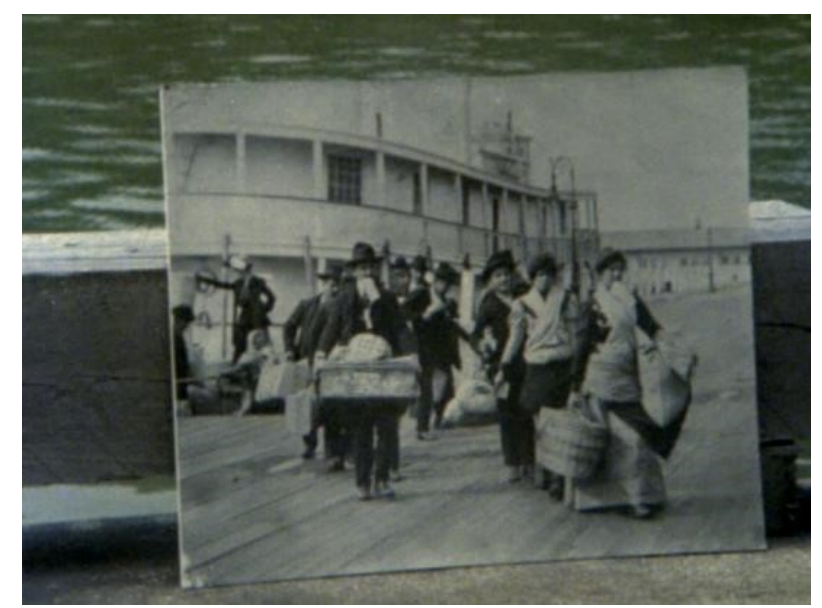

Figura 7. Montagem da imagem atual com as fotos antigas, presente em várias cenas do documentário.

dono daquelas pessoas representadas nas fotos, certa "humanidade", a partir do momento em que nos forçamos a discerni-las individualmente, a tentarmos imaginar suas histórias únicas e peculiares.

A sensação da leitura do texto, juntamente com as imagens que compõem esse texto, é de uma verdadeira viagem no tempo, nessa constante instabilidade e confusão entre presente e passado, entre histórias individuais misturadas a uma grande história coletiva. As imagens reforçam essa sensação de confusão, desconforto, ao observarmos um tempo que já não existe mais.

Como restituir esse passado, esses destinos incertos? Como contar uma história da qual não fizeram parte? Como olhar para essa imagem sem correr o risco ou a tentação de tentar imaginar um destino diverso para cada uma dessas pessoas totalmente desconhecidas para nós? Diante da impossibilidade dessa reconstituição só nos resta contemplar a imagem atual, a certeza inevitável do tempo que já passou e que deixou alguns rastros: a imagem atual só pode querer nos revelar a passagem do tempo, o abandono e os vestígios dos que ali estiveram. Ela não será capaz de responder as perguntas do início desse parágrafo. $\mathrm{O}$ trabalho de mostrar a imagem, porém, nos fará ao menos refletir sobre a história sem respostas:

Uma obra fotográfica é incessantemente reinterpretável à medida que a ordem das imagens nunca é imposta como a ordem das frases de um romance, mesmo que a obra fotográfica seja apresentada em um livro; a liberdade é muito maior diante de um livro de fotos que diante de um romance, diante de uma foto que diante de uma simples página. [...] A melhor abordagem da 
fotografia é poética. Essa liberdade diante da foto explica a dificuldade que o receptor sempre sente diante dela: como abordá-la? Como entrar em sua poesia? Como deslocá-la para a arte? O observador é muito mais livre que no cinema e sempre pode ser ofuscado pelo fenômeno fotografado. (Soulages, 2010: 200).

Essa liberdade de interpretação possivelmente nos leva a querer também refletir sobre questões individuais, faz com que nos interroguemos também sobre as próprias questões fundamentais para os realizadores do projeto. Por que Perec e Bober se interessam por essas vidas, individualmente? Como enxergam a imagem que enxergamos acima? Será possível enxergar algo a partir desse vazio que se coloca na foto? A ausência não é possível de enxergar, mas de compreender, a partir de imagens como essa.

Assim como nos inspiramos acerca dessas reflexões após a leitura de Ellis Island, também imaginamos tamanha inspiração que Bober e Perec tinham nas mãos. Observar primeiramente as fotos de Lewis Hine (que por si só já se constituem como obra de arte) e a partir dessas imagens conceber novas imagens (a partir do presente), um texto literário que tente dar conta dessa intersecção entre presente e passado e, por fim, realizar um documentário que envolva todas as manifestações artísticas aqui citadas.

É como se o trabalho de Bober, ao término das filmagens de Récits d'Ellis Island, fosse um grande ato final, impossível de ser concebido antes de todas essas etapas precedentes. O contato com fotos antigas, a visita ao local atual, a coleta de imagens do presente e a confrontação desses dois tempos que gerou o texto literário (e esse texto estará no filme, em forma de comentários narrados por Perec). Impossível dissociar, então, presente e passado. Eles são, juntos, a partir das fotos, os responsáveis pela realização do livro/filme.

Não parece angustiante voltar no tempo e nos deparar com essas famílias, mesmo que seja só uma imagem? A incorporação da foto antiga, junto ao cenário do presente, significa incorporar um novo olhar sobre algo já visto anteriormente.

A fotografia é enigma: incita o receptor a interpretar, a questionar, a criticar, em resumo, a criar e a pensar, mas de maneira inacabável. Ela é antidogmática: é dúvida e colocação em dúvida; é interrogação sobre a existência e sobre o tempo, sobre a matéria e sobre a imagem. Não podemos esgotar uma foto, pois, por meio dessa tensão entre seu material e seu referente para sempre perdido, ela nos escapa como nos escapam o mistério do outro, a realidade do mundo exterior, o problema da existência, a separação do passado, o enigma da morte ou a identidade do nosso eu. (Soulages, 2010: 346).

Assim, os realizadores nos conduzem a um novo olhar. Ellis Island, segundo o guia turístico repete insistentemente durante a visita, não é só um ponto de chegada e partida de milhares de pessoas. 
A partir do trabalho de Perec e Bober passamos a olhar pelo viés, pelo peculiar, pelo "buraco da fechadura": estamos diante de centenas de milhares de detalhes possíveis de serem imaginados, apesar de impossíveis de reconstituição. Os autores colocam a vida dessas pessoas por eles retratadas dento de um contexto menos histórico e mais pessoal, mais cotidiano, mais peculiar e, assim, fazem com que o documentário seja uma expressão também em primeira pessoa, mesmo que de maneira indireta.

Como dito anteriormente, é impossível retratar a história somente a partir de dados históricos. Aqui, o texto literário e as manipulações de imagens proporcionarão aos leitores efeitos mais marcantes: esse trabalho de individualização será muito mais evidente no momento em que entrevistam algumas pessoas, quando as colocam na posição de interlocutores.

Mas, as pessoas também são particularizadas a partir das montagens das fotos, já que nosso olhar se volta exclusivamente para elas. É como se Bober e Perec desejassem "arrancá-las" da multidão do passado e trazê-las para perto, escutá-las; como se quisessem tomar notas para incluí-las em seu trabalho de pesquisa.

Não deixa de ser um trabalho que parte do histórico para um caráter mais poético, mais "humano" e, consequentemente, autobiográfico: Ellis Island se torna então um lugar propício para homenagear cada uma dessas pessoas; individualmente quando possível. Seus rostos são mostrados, mesmo que não haja nomes para eles. É um momento para imaginarmos junto com os autores, o que pode ter sido a vida de cada uma dessas pessoas. Como leitores criaremos, ao olharmos para cada rosto, também um destino possível para eles. Essa será a nossa criação como leitores e espectadores: a partir do olhar,ser capaz de supor, imaginar e refletir; nosso olhar será tão profundo quanto o olhar dos autores:

Perec e Bober recusam a reconstituição pura e simples das salas pelas quais transitaram os emigrantes e oferecem aos lugares, através da encenação singular das fotografias nos vestígios de Ellis Island, uma outra dimensão e uma profundidade, uma reflexão sobre a ausência e a ausência de vestígios. ${ }^{6}$ (Tourneur, 2009: 14).

Os efeitos dessa transposição entre presente e passado são acentuados pela sensação de "realidade" transmitida por fotos que se apresentam em tamanhos ampliados que nos dão uma quase "ilusão" de que os tempos possam ser incorporados um ao outro. Longe de desejarem confundir ou "enganar" o

6. No original: "Perec et Bober refusent la reconstitution pure et simple des salles par lesquelles transitèrent les émigrants et offrent aux lieux, à travers la mise en scène singulière des photographies dans les vestiges d'Ellis Island, une autre dimension et une profondeur, une réflexion sur l'absence et l'absence de traces". 
leitor/espectador, Perec e Bober parecem desejar, realmente, evidenciar esse estranhamento dos tempos, essa superposição entre presente e passado.

Outros detalhes reforçam essa estratégia: o preto e branco da foto sobreposto à imagem atual mostra a nítida diferença entre o lugar da foto e do filme; as fotos, mesmo que antigas, dão uma sensação de "atualidade" ausente nas imagens atuais, já que destruídas, abandonadas. A degradação de Ellis Island no momento da filmagem "se opõe à impressão de conservação e de bom estado dos lugares que emanam as fotografias, produzindo uma impressão de contemporaneidade mais próximo que o próprio lugar" (Tourneur, 2009: 15).

Nada mais banal do que o olhar perdido de uma jovem que não sabe minimamente o que esperar de um mundo até então desconhecido para ela. O olhar dessa jovem é o que interessa a Perec, é o que conduz o trabalho de Bober: não há certezas, não há informações, mas há reflexões e esperanças. Passado e presente se unem para que nos questionemos sobre o futuro: "o que foi o futuro dessa jovem?", ou "O que pode ser o futuro de nossa humanidade?"

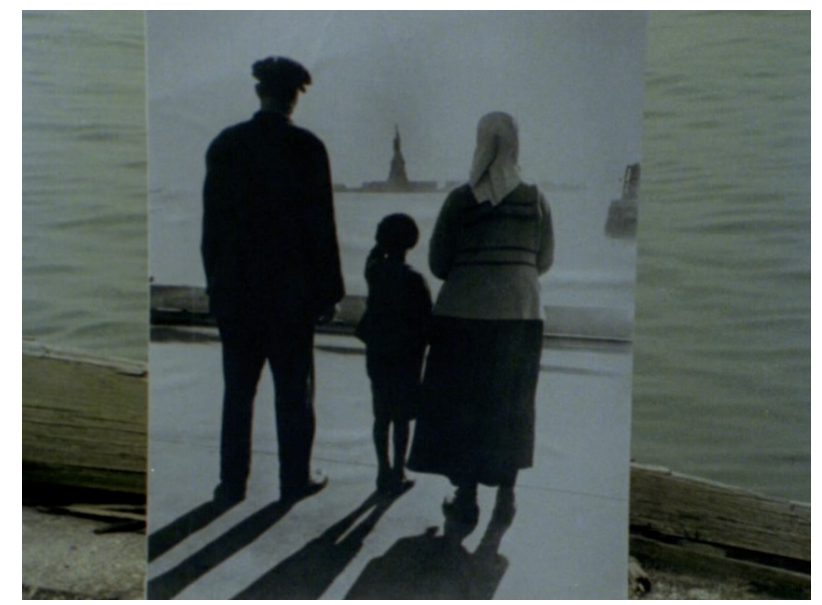

Figura 8. Montagem em uma das cenas do documentário: a imagem da foto fixa (escolhida para ilustrar a capa do livro) se contrapõe à imagem do movimento do mar; sua travessia representou a esperança para milhões de emigrantes.

\section{Considerações finais}

De certa forma, quando Perec e Bober se utilizam dessas fotos de arquivo mesclando-as com fotos atuais do lugar vazio - ou quando resolvem entrevistar alguns desses emigrantes localizados -, promovem uma "atualização" do 
tempo, ou, melhor dizendo, uma fusão de tempos que tratam de traços do passado, ao mesmo tempo em que pensam sobre o próprio presente e o futuro, a partir do contato com esse lugar que não conheciam, onde estão pela primeira vez, na tentativa de "resgatar" para si algum momento, alguma experiência, algum instante deste passado que não pode mais voltar, mas que insiste em circundar suas vidas.

A técnica de montagem utilizada pelos realizadores traz essa originalidade de "confrontar" os tempos, colocá-los em relação, fazer com que o leitor/espectador reflita sobre essa impossibilidade de retorno, sobre esse questionamento eterno diante da memória.

Colocar a foto de arquivo de volta à situação do passado, brincar com o tempo, posicioná-la quase exatamente no mesmo lugar em que foi tirada muitos anos antes, em uma tentativa de dar novamente a essa imagem um espaço concreto, uma ligação com o tempo presente.

Esse procedimento não será capaz de restaurar o contexto histórico da imagem, pelo contrário, será capaz de explicitar definitivamente que essa restauração é impossível, e talvez até indesejável, já que "a foto não rememora o passado". (Barthes, 1984: 123).

A questão que se coloca, então, pode ser outra: a ilha $W$, fazendo alusão aos campos, não foi capaz de contar ou mostrar tudo aquilo que o autor desejava explicitar, ou seja, contar sua autobiografia (que inclui a morte dos pais na Segunda Guerra Mundial). A impossibilidade de reconstituir o que se passou nos campos ressoa na impossibilidade de restituir o tempo em Ellis Island. Mas, ao menos nessa ilha, Perec e Bober puderam estar presentes e puderam contar, cada um à sua maneira, sua própria história em primeira pessoa. Constataram, definitivamente, que o indizível está nas palavras, está nas imagens. E que a ausência e o desaparecimento são capazes de produzir arte. "O fundamental de Ellis Island não é unicamente o que ele foi em meados de 1900, mas o que ele representa para Perec e Bober em 1979, e para nós hoje" (Nordholt, 2008: 300).

\section{Referências bibliográficas}

Barthes, R. (1984). A câmara clara: nota sobre a fotografia. Rio de Janeiro: Nova Fronteira.

Barthes, R. (2003). La préparation du roman I et II. Cours et séminaires au Collège de France (1978-1979 et 1979-1980, Paris: Seuil/IMEC.

Barthes, R. (1981). Sobre a fotografia. O grão da voz, Lisboa: 70. 
Bober, R. \& Perec, G. (1995). Récits d'Ellis Island - histoires d'errance et d'espoir. Paris: P.O.L.

Bober, R. (2006). Entretien: Le regard et l'absence. Cahiers Georges Perec. Le cinématographe, 9 : 245-254. Paris.

Hartje, H. \& Neefs, J. (1993). Georges Perec: Images. Paris: Seuil.

Lawniczak, M. (2006). L'autre île. Cahiers Georges Perec. Le cinématographe, 9 : 229-244. Paris.

Nichols, B. (2008). Introdução ao documentário. São Paulo: Papirus.

Perec, G. (1975). W ou le souvenir d'enfance. Paris: Denöel.

Perec, G. (1995). W ou a memória da infância. São Paulo: Companhia das Letras.

Soulages, F. (2010). Estética da fotografia: perda e permanência. São Paulo: Senac.

Tourneur, C. (1980). Les dispositifs de fiction cinématographique au sein du documentaire Récits d'Ellis Island, de Georges Perec et Robert Bober. Disponível em: http://cm.revues.org/357

\section{Filmografia}

Récits d'Ellis Island (1980), de Robert Bober e Georges Perec 